\title{
BETWEEN PROPER NAME AND APPELLATIVE: LEXICOGRAPHY OF WORDS WITH BORDERLINE STATUS (EXEMPLIFIED BY NEOLOGISM BREXIT) ${ }^{1}$
}

\author{
Anna V. Shchetinina \\ Ural Federal University named after the First President of Russia B.N. Yeltsin, Yekaterinburg, Russia
}

\begin{abstract}
The problems of lexicography of new words that appeared in the Russian language in the $21^{\text {st }}$ century are considered based on the materials of the upcoming thematic Explanatory Dictionary of Unity and Enmity in the Russian Language of 2000-2020. The author of the article is one of the dictionary compilers. It is stated that the difficulties of describing new borrowed lexical units, that are at the stage of usage, are associated with the establishment of their lexical, grammatical and stylistic characteristics. Criteria for their determination are proposed. The principles of choosing the variant of heading word spelling in a dictionary entry are argued. Based on the methods of definitional, linguoculturological and content analysis using textual material extracted from mass media resources, a methodology for compiling a dictionary entry has been developed, which makes it possible to give a detailed description of the lexical, grammatical, stylistic, paradigmatic and pragmatic characteristics of current borrowings. As a result of this technique application, a dictionary entry of Brexit neologism is presented, reflecting the unstable position of this lexeme in the Russian language system, the status of which fluctuates between a proper name and an appellative. The material and methodology for its systematization can be considered when compiling explanatory dictionaries of new words in the Russian language.

Key words: lexicography, neologism, borrowing, semantics, cultural linguistics, pragmatics.

Citation. Shchetinina A.V. Between Proper Name and Appellative: Lexicography of Words with Borderline Status (Exemplified by Neologism Brexit). Vestnik Volgogradskogo gosudarstvennogo universiteta. Seriya 2. Yazykoznanie [Science Journal of Volgograd State University. Linguistics], 2021, vol. 20, no. 5, pp. 32-42. (in Russian). DOI: https://doi.org/10.15688/jvolsu2.2021.5.3
\end{abstract}

\section{МЕЖДУ ИМЕНЕМ СОБСТВЕННЫМ И АПЕЛЛЯТИВОМ: ЛЕКСИКОГРАФИРОВАНИЕ СЛОВ С ПОГРАНИЧНЫМ СТАТУСОМ (НА ПРИМЕРЕ НЕОЛОГИЗМА БРЕКСИТ) ${ }^{1}$}

\author{
Анна Викторовна Щетинина \\ Уральский федеральный университет им. первого Президента России Б.Н. Ельцина, \\ г. Екатеринбург, Россия
}


контент-анализа с использованием текстового материала, извлеченного из массмедийных ресурсов, выработана методика составления словарной статьи, позволяющая дать развернутое описание лексических, грамматических, стилистических, парадигматических и прагматических характеристик актуальных заимствований. В качестве результата ее применения представлена словарная статья неологизма Брексит, отражающая неустойчивое положение этой лексемы в русском языке: ее статус колеблется между именем собственным и апеллятивом. Материал и методика его систематизации могут быть учтены при составлении толковых словарей новых слов русского языка.

Ключевые слова: лексикография, неологизм, заимствование, семантика, лингвокультурология, прагматика.

Цитирование. Щетинина А. В. Между именем собственным и апеллятивом: лексикографирование слов с пограничным статусом (на примере неологизма Брексит) // Вестник Волгоградского государственного университета. Серия 2, Языкознание. - 2021. - Т. 20, № 5. - С. 32-42. - DOI: https://doi.org/10.15688/ jvolsu2.2021.5.3

\section{Введение}

Получить представление о том, как в современном массмедийном пространстве называются люди, предметы, события, процессы и факты действительности, репрезентирующие единение и вражду, позволяет обращение к лексикографическим источникам. В связи с этим важно осуществлять регистрацию и описание новых слов как в отдельных исследованиях, так и в толковых словарях. Отражение в них лексико-грамматических, семантических, стилистических, сочетаемостных характеристик, парадигматических связей новых языковых фактов позволяет оценить устойчивость того или иного слова или выражения, их закрепленность в системе русского языка, понять, в каких значениях они функционируют в речи, в какой сфере преимущественно используются.

Результаты изучения новых слов в разные периоды развития языка получили отражение в работах, посвященных неологии и неографии [Буцева, Ридецкая, 2018; Гак, 1983; Гацалова, Парсиева, 2015; Дубичинский, 2016; Дуличенко, 1994; Котелова, 2015; Маринова, 2011; Неология и неография..., 2016; Новые слова..., 2020; Новые тенденции ..., 2016; Попова, 2008; Шулежкова, 2019; и др.], и в толковых словарях как результате изучения и фиксирования новых для определенного периода языковых фактов (Григоренко; Катлинская; Крысин; Новиков; Новые слова и значения; Окунцова; Словарь языка интернета.ru; Шагалова; и др.). При этом в последних выбор регистрируемых номинаций и объем словарной статьи могут различаться в зависимости от задач, которые ставят перед собой авторы. Так, «Самый новейший толковый словарь русского языка XXI века : ок. 1500 слов» Е.Н. Шагаловой содержит новую лексику первого десятилетия ХХ в. разных тематических групп, а в словарной статье дается толкование слова, грамматическая характеристика, этимологические сведения, в ряде случаев - орфографические варианты и синонимы (Шагалова). «Словарь языка интернета.ru» фиксирует языковые факты, выявленные в текстах интернеткоммуникации, преимущественно в сетевом общении, и, помимо традиционно включаемой в словарное описание информации (грамматическая характеристика, толкование, примеры употребления и т. д.), предлагает культурологические комментарии и в некоторых случаях рисунки (Словарь языка интернета.ru).

Готовящееся к публикации издание «Толковый словарь лексики единения и вражды в русском языке 2000-2020 годов», одним из разработчиков которого является автор данной статьи, содержит слова и выражения, появившиеся в последние 20 лет (подробнее об этом см.: [Щетинина, 2021]). В словаре регистрируются языковые единицы, во-первых, развившие новые значения (бомбить 'выражать недовольство', ватник 'русский патриот', токсичный 'негативно влияющий на окружающих' и др.), во-вторых, образованные от уже имеющихся в русском языке основ морфологическими способами (вписка 'молодежная вечеринка на квартире', импортозамещение 'производство отечественных товаров вместо иностранных', санкционка 'запрещенные иностранные товары' и др.), в-третьих, заимствованные из других языков, преимуществен- 


\section{РАЗВИТИЕ И ФУНКЦИОНИРОВАНИЕ РУССКОГО ЯЗЫКА}

но английского, в принимающем языке (русском) адаптированные в разной степени (кринжевать 'испытывать чувство отвращения', локдаун 'строгое ограничение непосредственных контактов людей, доступа к общественным местам', харассмент 'домогательства' и др.). Можно выделить особые языковые единицы типа крымнаш, яжемать, Брекcum и другие номинации, лексикографирование которых в настоящее время дискуссионно. Поэтому требуется разработка правил их словарной репрезентации.

\section{Материал и методы исследования}

Регистрация новейших слов - их значений, грамматических и стилистических свойств, прагматических характеристик основывается на методиках включенного наблюдения, контент-анализа и компонентного анализа, традиционно используемых в лексикографической практике. В данном исследовании представим лексикографическое описание слова Брексит, которое определяется нами в толковом словаре новой лексики в тематическую группу номинаций со значением вражды, охарактеризуем его лексикограмматические и стилистические характеристики и прагматический потенциал.

\section{Результаты и обсуждение}

Словарная статья позволяет зафиксировать широкий круг признаков нового слова. Ее структура в создаваемом словаре включает следующие элементы: заголовочное слово, грамматические характеристики, сведения о происхождении слова, стилистические пометы, дефиницию, иллюстрации, сведения о сочетаемости слова, информацию об эквивалентных данной лексеме единицах, синонимах, антонимах, родственных словах.

\section{Методика составления словарной статьи для неологизма Брексит}

В лексикографическом описании заголовочное слово представлено в разных вариантах, которые встречаются в СМИ (Брекcum, Брекзит, брекзит, брексит, Brexit). Так как это калькированное заимствование стало использоваться в русской речи относительно недавно, на протяжении всего времени его функционирования встречались разные написания, поэтому мы приводим все выявленные в текстах СМИ варианты данной единицы: прописная и строчная буквы (Брексит / брексит), $c$ и з (Брексит / брекзит), в кавычках и без («брексит» / брексит), в латинской графике, поскольку такой вариант тоже встречается в русскоязычных статьях (Brexit). При этом в качестве слова, представленного первым в общем ряду вариантов, мы выбрали Брекcum, в связи с тем, что в 2020 г. в большинстве текстов массмедиа установилось именно такое написание.

Например, в газете «Коммерсантъ» за 2020 - начало 2021 г. из 133 статей, в которых используется лексема, только в 3 встречаются варианты написания со строчной буквы с согласной $c$ в середине слова (брекcum), при этом все 130 вариантов с прописной буквы заключены в кавычки (можем предположить, как название определенной программы):

(1) Потери британских экспортеров из-за нетарифных ограничений в первый год после «Брексита» в зависимости от динамики курса фунта стерлингов могут составить от $€ 13,5$ млрд до $€ 27,3$ млрд $(0,6-1,1 \%$ ВВП) (АА. «Брекситу» назвали цену нетарифных издержек // Коммерсантъ. 2021. 22 янв. (№ 10). C. 2).

Отметим, что в Национальном корпусе русского языка представлены 169 контекстов из газеты «Коммерсантъ» со словом Брексит и 19 других написаний из текстов разных источников: «Новая газета», «Московский комсомолец» и др. В «Аргументах и фактах» за последний год встречается написание слова и с прописной, и со строчной букв, в кавычках (редко) и без: Брексит / брексит, в редких случаях англоязычное Brexit:

(2) Да и перипетии Брексита в Великобритании оставляют немало вопросов по поводу британских верхов (АА. Сеансы спиритизма... // АиФ. 2020. 16 сент.);

(3) В британском парламенте представили доклад об итогах расследования вмешательства России в брексит (АА. Почему Россию оболгали, но не извинились? // АиФ. 2020. 29 июля). 
На сайте «RT на русском» преобладает такое же написание:

(4) Эрдоган: членство Турции в ЕС устранит внесённую брекситом неопределённость (AА. RT на русском. 2021. 12 янв.),

более 300 контекстов, причем преимущественно со строчной буквы, против 2 примеров Брекзит в 2016 и 2018 годах.

В «Российской газете» представлено 155 вариантов брекзит за все годы против 54 брексит, причем как с прописной, так и со строчной буквы, в кавычках и без:

(5) Старая добрая Англия, зарулившая в нечто непонятное по имени Брекзит и оттолкнувшаяся багром от европейского континента, стала сегодня чужой для миллионов своих граждан (АА. Гуд-бай, Туманный Альбион! // Российская газета. 2020.6 авг);

(6) Несмотря на «брексит» и отчалившую от берегов «единой Европы» Британию, язык Шекспира не стал реже использоваться в брюссельских коридорах власти (АА. Устали от английского // Российская газета. 2020. 27 сент.).

В текстах «РИА Новости» за весь рассматриваемый период также преобладает написание Брекзит / брекзит - 132 против 32 Брексит / брексит.

То же разнообразие написаний анализируемой лексемы представлено в научном дискурсе, однако в политологических работах это слово употребляется преимущественно как имя собственное, называющее единичное историческое событие, в том числе в оригинальном виде (Brexit), в отличие от частотного использования апеллятивного варианта в текстах СМИ.

Из вышесказанного следует, что общепризнанного написания данной языковой единицы сегодня нет. Однако в последние годы в большей части источников преобладает вариант с буквой $c$, в связи с чем, на наш взгляд, его можно вынести первым в ряду вариантов заголовочного слова. Мы склонны рассматривать данную единицу как имя собственное, поскольку в большей части контекстов оно употребляется в прямом значении 'историческое событие', а традиционно названия исторических событий в русском языке пишутся с прописной буквы без кавычек (ср. Ренессанс,
Октябрь, Парижская коммуна, Версальский мир и др.), поэтому и примеры лексикограмматической сочетаемости представлены с вариантом написания Брексит.

Грамматическая характеристика анализируемого слова в создаваемом словаре включается согласно традиционным правилам ее представления в толковых словарях общего типа. После начальной формы существительного указывается его окончание в родительном падеже единственном числе, частеречная и родовая принадлежность лексемы (Брексит, -а, сущ., м. р.).

В грамматическом аспекте интересна практика употребления данного слова как имени собственного или апеллятива. С одной стороны, единица Брексит обозначает историческое событие, появилась и функционирует в настоящее время в разных написаниях, в том числе в оригинальном (Brexit), следовательно, вполне закономерно является именем собственным. С другой, как уже отмечалось выше, она активно репрезентируется в текстах официальных СМИ и вариантом написания со строчной буквы, причем в том жезначении, как номинация единичного понятия.

Кроме того, слово используется и во множественном числе, что является признаком имени нарицательного:

(7) Это мощная опора для планеты, если она исчезнет - быть беде», - поделился своим мнением Лукашенко, добавив, что не воспринимает «все эти ваши брекситы и националистические движения» (АА. А. Ильин. Разворот Лукашенко: Минск пообещал работать на благо «имперского» Евросоюза // Московский комсомолец. 2017. 15 марта);

(8) Трампом Ле Пен, новые «брекситы», а там не за горами и Россия снова в роли великой державы - Россия без кризиса и коррупции ... (АА. Н. Миронов. Трампа хватит ненадолго // Московский комсомолец. 2016. 23 нояб.).

За несколько лет у данной лексической единицы постепенно развивается значение апеллятива, что свойственно русскому языку, ср.:

(9) Возможно, и русской культуре предстоит пережить Ренессанс (НКРЯ. М. Харитонов. Стенография конца века. Из дневниковых записей. 2007);

(10) «Я - русский, и потому имею право презирать все эти ренессансы, рококо и готики! - кри- 
чал он иногда, стуча себя в грудь...» (НКРЯ. Л. Кассиль. Дело вкуса, 1964).

Если предположить, что слово брексит может называть класс предметов, а это характерно для апеллятивов, то его употребление во множественном числе вполне закономерно. До появления единицы Brexit в СМИ и научной литературе уже использовалась лексема Grexit / Грексит ('возможный выход Греции из еврозоны и Европейского Союза в 2014 2015 годах'):

(11) Вероятность Grexit - такое название получило событие (от Greece и Exit) - увеличилась до 50-75 \% с прежних 50 \%, считают аналитики Citi. (АA. Grexit с кризисом ожидается в июне // Вести. 2012. 15 мая);

(12) In this paper we consider whether the potential of Greece's exit (GrExit) from the Eurozone has an impact on Greece's economic adjustment program and vice versa (AA. Koutsoukisa N.-S., Spyros A. R. The GrExit Paradox // Procedia Economics and Finance. 2014. № 9. Р. 24-31) - В этой статье мы рассмотрим, влияет ли потенциал выхода Греции (GrExit) из еврозоны на программу экономической адаптации Греции, и наоборот (здесь и далее перевод наш. $-A$. Щ.).

Более того, исследователи отмечают, что в европейских СМИ вслед за аналогичными Брекситу политическими целями других стран появились номинации: Auxit (Austria + exit) 'возможный выход Австрии из Европейского Союза', Czechit (Czech + exit) 'возможный выход Чехии из Европейского Союза', Fixit (Finland + exit) 'возможный выход Финляндии из Европейского Союза', Frexit (France + exit) 'возможный выход Франции из Европейского Союза' и др. [Катермина, Соловьева, 2019, с. 107; Мозырева, 2017, с. 117; Nasseri, 2016]:

(13) FIXIT 'LIKELY': EU set for ANOTHER political earthquake as Finland exit 'on the cards' (AA. Rogers J. Express, Fri, Apr 21, 2017 / FIXIT 'LIKELY’) ЕС готовится к очередному политическому землетрясению, поскольку “на карте” выход Финляндии.

В российских СМИ, статьи которых посвящены европейским событиям, также встречаются такого рода новообразования:

(14) Финляндия собрала пятую часть от необходимого количества подписей для рассмотрения вопроса о проведении референдума о членстве в ЕС в парламенте страны. По мнению инициаторов сбора голосов в пользу Fixit, ЕС лишь сеет в Европе хаос, и Финляндии необходимо освободиться (АА. После Brexit Финляндия собирает подписи за Fixit // Вести.ru. 2016. 25 июня);

(15) Обозреватель Лоран Эрбле предрек Frexit (выход Франции из ЕС по аналогии с Brexit). Об этом он написал в своей статье для Le Figaro (AА. Европе предрекли Frexit // Lenta.ru. 2021. 14 марта).

Согласимся с мнением В.В. Катерминой и В.С. Соловьевой о том, что «продуктивность модели объясняется не только языковыми, но и экстралингвистическими факторами. Brexit в современном политическом мире уже представляет собой целый сценарий развития политической ситуации» [Катермина, Соловьева, 2019, с. 107]. Следовательно, фактор повторяемости или - в данном случае - возможной повторяемости явления обусловливает образование множественного числа существительного, называющего целый класс явлений, и утрату им значения 'единичное историческое событие', что позволяет говорить о формировании новой, пока неузуальной, модели образования слова со значением 'выход страны из Европейского Союза'.

Большинство неологизмов в русском языке относится к заимствованиям, поэтому указание на источник (или историю) их появления рассматривается авторами как значимая составляющая словарной статьи. Благодаря данному типу информации можно установить связь со значением иностранного слова, установить соответствие семантики неологизма и его источника. Так, слово Брексит заимствовано из английского языка, в котором появилась лексема Brexit, образованная путем сложения усеченной основы первого слова Britain (Британия) и целой второго exit (выход), в результате чего можно сформулировать буквальное значение 'выход Британии'. Отметим, что фиксирование в словаре новых русских слов, образовавшихся посредством переосмысления уже имеющихся значений либо другими способами, предполагает в каждом случае изучение истории образования номинации в русском языке новейшего периода и ее представление в словарной статье.

Особая сложность в процессе лексикографирования неологизмов состоит во включении 
в метаязыковое описание слова стилистических помет, поскольку однозначно определить стилистическую закрепленность языковой единицы зачастую не представляется возможным в силу ее активного использования в текстах разной тематики и различных сфер функционирования. Однозначно, на наш взгляд, устанавливается только принадлежность единиц к группе неологизмов. Так, стилистическая и тематическая принадлежность слова Брексит определяется достаточно легко: единица характерна для публицистической и политической сфер, поскольку лексема появилась как номинация исторического события в политической жизни Великобритании и получила распространение в русском языке через тексты СМИ. В то же время, например, слово абьюз, образованное от словосочетания абьюзивные отношения, трудно идентифицировать однозначно с точки зрения стилистической принадлежности. С одной стороны, оно используется в текстах СМИ, хотя и не частотно («Коммерсантъ»- 28 вхождений, «АиФ» - 7, «Cosmopolitan» - 87 и т. п.), с другой - является профессионализмом, то есть жаргонным словом из сферы психологии, активно функционирует в интернет-коммуникации (блоги, комментарии, форумы и др.; более 6 тыс. вхождений показывает Яндекс) при обсуждении проблем психологического насилия в разных сферах жизни. Следовательно, можно рассматривать лексему абьюз как жаргонную из сферы психологии и зафиксировать в словаре с пометой 'профессионализм / профессиональный жаргон'.

Следующая часть словарной статьи семантема - включает традиционно выделяемые семы: ядерную ('политическое событие'), дифференциальные (на ближней периферии: 'выход Великобритании' ‘из Европейского Союза', 'связанная с ним процедура'; на дальней периферии: 'на основании решения референдума', '2016 год').

Иллюстративный материал призван продемонстрировать использование слова в разнообразных грамматических формах, с различными смысловыми оттенками, в разные периоды последнего двадцатилетия. Лексема Брексит может быть представлена в иллюстрациях из статей с 2016 по 2021 г. в разных вариантах написания и грамматических формах.
Сведения о типовой сочетаемости неологизма демонстрируют особенности его употребления в речи. Например, Брексит в текстах образует словосочетания с существительными в родительном падеже (сторонники / противники Брексита - данная сочетаемость определяется значением конфликтного события, исход которого определялся голосованием сторонников и противников на референдуме; процесс Брексита - сочетаемость определяется значением длительности мероприятия) и глаголами (провести Брексит, осуществить Брексит, выступать за / против Брексит (a), решить после Брексита, спровочировать Брекситом и др.), поскольку Брексит представляет собой процедуру, включающую ряд действий определенных акторов, у этих действий есть причины, последствия и т. д. Отражение типовой сочетаемости особенно актуально для пользователей словаря, поскольку неологизмы могут быть им незнакомы, но интересны с точки зрения понимания возможности их употребления.

Выявление парадигматических связей неологизмов (эквивалентных лексем, антонимов, однокоренных слов) позволяет определить место новых заимствований, которое они уже заняли в системе русского языка.

$\mathrm{C}$ точки зрения образования дериватов слово Brexit в английском языке более продуктивно по сравнению с русским. Как показывают результаты анализа британского медиадискурса, проведенного И.И. Каштановой, О.А. Бирюковой, Е.А. Давыдовой, «за короткий срок были придуманы и закрепились в английском языке такие производные слова, как Brexiteer - сторонник Брексита, Bremoaner - противник Брексита, Brexcuse упоминание о Брексите в попытке объяснить свои неудачи, Brexodus - массовый отъезд частных лиц и компаний из Великобритании в связи с Брекситом, Brexicon - новые слова и выражения, используемые для обсуждения Брексита» [Каштанова, Бирюкова, Давыдова, 2018, c. 296].

Из множества производных лексемы Brexit, появившихся в английском языке, в текстах российских медиа встречаются немногие, в частности, антонимичные дериваты брекситер и бремейнер, также калькированные с английского brexiter со значением 'сто- 
ронник Брексита' и bremainer 'противник Брексита':

(16) Вторая поправка снижает шансы Мэй на переговорах в Брюсселе. Тем не менее, «брекситеры» и «бремейнеры» (сторонники членства в ЕС «МК») из фракции консерваторов пришли к компромиссу (АА. Брексит буксует: Мэй отправили в Брюссель решать невыполнимую задачу // Московский комсомолец. 2019. 30 янв.);

(17) На время прежнее размежевание на правых и левых уступило размежеванию на брекзитеров и бремейнеров (АА. Е. Ананьева. Brexit: да, но нет // РСМД. 2019. 5 нояб.).

В этом отношении лексема Брексит отличается от многих новых заимствованных слов, которые уже образовали связи с другими единицами языка. Например, упомянутое выше слово абьюз имеет как литературные, так и жаргонные эквиваленты: абьюзивные отношения, буллинг, газлайтинг, насилие, подавление, прессинг, неглект; однокоренные слова: абьюзер, абьюзивный, абьюзить. Данное явление, вероятно, объясняется тем, что политические номинации такого типа, как Брекcum, Грексит, в связи с чуждостью иноязыкового материала и жесткой структурированностью сложного слова не попадают в сферу речевого творчества авторов текстов. Имеющиеся производные брекзитер и бремейнер также кальки с английского и употребляются только в контексте политического события, с ними связанного. Напротив, в английском языке, как отмечалось выше, на основе лексемы Brexit создано много новых слов, которые образованы разными способами, в том числе и в результате языковой игры, например название кризисной ситуации в королевской семье, возникшей в связи с отказом принца Гарри и его жены Мэган Маркл от своих полномочий:

(18) Megxit Meghan Markle and Prince Harry have created a royal crisis 'worse than the abdication', according to royal author Penny Junor, speaking on the first anniversary of Megxit (AA. Meghan and Harry Have "Lobbed Huge Bomb" with Megxit Crisis "Worse than Abdication" // Mirror. 2021.31 Mar.) Меган Маркл и принц Гарри спровоцировали кризис в королевской семье, который «хуже, чем отречение», по словам королевского биографа Пенни Джунора, выступившего в первую годовщину Мегксита;
(19) После этого Брэд переключился на другое громкое событие - «Мегзит», как британцы назвали сложение полномочий Меган Маркл и принцем Гарри (АА. Брэд Питт смутил Кейт Миддлтон и принца Уильяма дерзкой шуткой о «Мегзите» // Cosmopolitan. 2020. 3 февр.).

\section{Описание неологизма Брексит}

в толковом словаре

Лексема Брексит заимствована из английского языка, относится к актуальной лексике, поскольку событие, номинируемое данной единицей, широко обсуждалось в массмедиа начиная с 2016 года.

Брексит (Брекзит, Брексит, брекзит, брексит, Brexit), -a, сущ., м., употребляется в речи как имя собственное и апеллятив.

Cр.: англ. Brexit: Britain (Британия) + exit (выход) - выход Британии.

Язык СМИ. Полит.

Политическое событие, представляющее собой выход Великобритании из Европейского Союза на основании решения референдума, проведенного в 2016 г., и связанная с ним процедура.

- Напомним, согласно опросу, проведенному неправительственной организацией Tech London Advocates, каждая третья лондонская технологическая компания опасается, что «Брексит» негативно повлияет на их деятельность (Beликобритания будет выдавать больше виз для специалистов технологической сферы // Коммерсантъ. 2017. 16 нояб.).

- Раньше Британия была полностью сосредоточена на Брекзите - болезненном и унизительном для страны прочессе ее выхода из Европейского союза. Теперь Брекзиту придется потесниться. На фоне ожесточенной схватки между Лондоном и Санкт-Петербургом за влияние в Центральной Азии в российском обществе ХІХ века было очень распространено выражение «англичанка гадит» (Чисто предвыборное убийство: как отравление Скрипаля изменит последний срок Путина // Московский комсомолец. 2018. 13 марта).

- Популярность UKIP и рост числа сторонников выхода Британии из Евросоюза, «брекзита» (по аналогии с «грекзитом», возможным выходом Греиии из еврозоны и ЕС), во многом обусловлены ростом миграции из других стран $E C$ в последнее десятилетие («Брекзит»: по тормозам // Эксперт. 2016. № 9).

- Президент Туричии Реджеп Тайип Эрдоган напомнил, что страна не отказалась от стрем- 
ления вступить в Европейский союз. По его мнению, неопределённость в ЕС, спровоцированная брекситом, будет устранена только после того, как Анкара присоединится к объединению европейских государств (Эрдоган: членство Турции... // RT на русском. 2021. 12 янв.).

- Великобритания начала свой первый год вне Европейского союза после реализации Brexit и завершения переходного периода (Интерфакс. 2021. 1 янв.).

ТИПОВАЯ СОчЕТАЕМОСТЬ: сторонники Брексита, противники Брексита, процесс Брексита, жесткий Брексит, спровоцировано Брекситом, провести Брексит, осуществить Брексит, выступать за / против Брексит(а), сосредоточиться на Брексите, решить после Брексита, период после Брексита.

ЭквивАЛЕнты: единичная номинация (название исторического события).

СР. ТАКЖЕ: Грексит - воЗмоЖНЫЙ вЫХод Греции из еврозоны и Европейского Союза. Мегзит конфликт в королевской семье из-за отказа принца Гарри и его жены Мэган Маркл от своих полномочий. Брекзитер - сторонник Брексита.

\section{Заключение}

Лексикографирование новых слов связано с определенными трудностями, обусловленными неустойчивым статусом этих единиц в системе языка. Фиксация неологизма в словаре требует осуществления скрупулезного анализа его употребления в разных видах дискурса. Для того чтобы пользователи словаря составили полное представление о том или ином новом слове, необходимо развернутое описание его лексических, грамматических, стилистических, парадигматических характеристик, а также прагматики использования новой языковой единицы в речи.

Лексема Брексит представляет собой сложный случай заимствования. С одной стороны, оно активно используется в письменной и устной формах речи (поисковый запрос в Яндексе показывает 2 млн результатов), главным образом в политическом дискурсе, и находится «у всех на слуху», поэтому не вызывает затруднения при восприятии у носителей языка; с другой - его статус как лингвистической единицы (написание и категориальная принадлежность к собственным или нарицательным именам) не является очевидным: слово находится в процессе узуализации, следова- тельно, его лексикографическое описание возможно с опорой на новые подходы к регистрации неологизмов в толковых словарях.

\section{ПРИМЕЧАНИЕ}

${ }^{1}$ Исследование выполнено при поддержке Российского научного фонда, проект № 20-6846003 «Семантика единения и вражды в русской лексике и фразеологии: системно-языковые данные и дискурс».

The study was supported by the Russian Science Foundation, project No. 20-68-46003 "Semantics of unity and enmity in Russian vocabulary and phraseology: system-linguistic data and discourse".

\section{СПИСОК ЛИТЕРАТУРЫ}

Буцева Т. Н., Ридецкая Ю. С., 2018. Неография и слово года // Русский язык в школе. № 8. С. 66-71.

Гак В. Г., 1983. Новые слова и новые словари // Новые слова и словари новых слов : сб. ст. / отв. ред. Н. З. Котелова. Л. : Наука. С. 15-29.

Гацалова Л. Б., Парсиева Л. К., 2015. Возможности терминологической интерпретации и лексикографическое отражение потенциальных слов // Вестник Волгоградского государственного университета. Серия 2, Языкознание. № 4 (28). C. 138-143. DOI: http://dx.doi.org/ 10.15688/jvolsu2.2015.4.17.

Дубичинский В. В., 2016. Основания неографии // Неология и неография: современное состояние и перспективы (к 50-летию научного направления) : сб. науч. ст. / отв. ред. Т. Н. Буцева. СПб. : Нестор-История. С. 41-47.

Дуличенко А. Д., 1994. Русский язык конца XX столетия. Мюнхен : Sagner. 347 с.

Катермина В. В., Соловьева Н. С., 2019. Аксиология неологизма Brexit в англоязычном массмедийном дискурсе // Актуальные проблемы филологии и педагогической лингвистики. № 3. С. 103-111.

Каштанова И. И., Бирюкова О. А., Давыдова Е. А., 2018. Концепт BREXIT в современном англоязычном медиадискурсе // Филологические науки. Вопросы теории и практики. № 10, ч. 2. C. 295-299.

Котелова Н. 3., 2015. Избранные работы. СПб. : Нестор-История. 276 с.

Маринова Е. В., 2011. Так говорили в 90-е... Размышления над страницами нового словаря // Русская речь. № 5. С. 118-125.

Мозырева О. В., 2017. Брексит, Тиндер и другие источники появления новых слов // Язык : кате- 
гории, функции, речевое действие : материалы X юбилейн. Междунар. науч. конф. к 75-летию Валерия Степановича Борисова. М. : Моск. пед. гос. ун-т : Гос. соц.-гуманит. ун-т. С. 117-120.

Неология и неография: современное состояние и перспективы (к 50-летию научного направления), 2016 : сб. науч. ст. / отв. ред. Т. Н. Буцева. СПб. : Нестор-История. 236 с.

Новые слова и словари новых слов. 2020, 2020 : сб. науч. ст. / отв. ред. Н. В. Козловская. СПб. : ИЛИ РАН. 220 с.

Новые тенденции в русском языке начала XXI века, 2016 : коллектив. моногр. / под ред. Л. В. Рацибурской. 4-е изд., стер. М. : Флинта : Наука. 304 с.

Попова М. А., 2008. Факторы и векторы процесса неологизации современного русского языка // Известия Волгоградского государственного педагогического университета. № 2 (26). C. $72-75$.

Шулежкова С. Г., 2019. Русские и болгарские фразеологические неологизмы как объект словарного описания // Научный диалог. № 9. С. 173189. DOI: 10.24224/2227-1295-2019-9-173-189.

Щетинина А. В., 2021. Ватник, брексит и крымнаш: к вопросу о лексикографировании новых слов с семантикой единения и вражды // Научный диалог. № 3. С. 139-155. DOI: 10.24224/ 2227-1295-2021-3-139-155.

Nasseri M., 2016. Why was it “Brexit”, not "Bristay"? A Note on the Psycholinguistic Effects of Message Exposure and Priming on Decision. URL: https:/www.researchgate.net/publication/ 312191534_Why_was_it_Brexit_not_Bristay_ A_Note_on_the_Psycholinguistic_Effects_of Message_Exposure_and_Priming on_Decision_Making_Pūblished_online_at httpwwwlalacademynetwhy-was-it-brexit-notbristay (date of access: 20.03.2021).

\section{ИСТОЧНИКИ И СЛОВАРИ}

$A A-$ Архив автора.

Григоренко - Григоренко О. В. Новые наименования лиц в современном русском языке : слов. материалы. Воронеж : Науч. кн., 2009. 517 с.

Катлинская - Катлинская Л. П. Толковый словарь новых слов и значений русского языка : ок. 2000 слов. М. : АСТ : Астрель, 2008. 380 с.

Крысин - Крысин Л. П. 1000 новых иностранных слов : справ. изд. М. : АСТ-ПРЕСС КНИГА, $2009.320 \mathrm{c}$.

НКРЯ - Национальный корпус русского языка. URL: www.ruscorpora.ru (дата обращения: 02.02.2021).
Новиков - Новиков В. И. Словарь модных слов: языковая картина современности. М. : Словари XXI века, 2018. $351 \mathrm{c}$.

Новые слова и значения - Новые слова и значения. В 3 т. Т. 3 : слов.-справ. по материалам прессы и лит. 90-х гг. ХХ в. СПб. : Дмитрий Буланин, 2014. $1360 \mathrm{c}$.

Окунциова - Окунцова Е. А. Новейший словарь иностранных слов : ок. 5000 слов и словосочетаний. М. : Айрис-пресс, 2009. 510 с.

Словарь языка интернета.rи - Словарь языка интернета.ru / под ред. М. А. Кронгауза. М. : АСТ-ПРЕСС КНИГА, 2016. 288 с.

Шагалова - Шагалова Е. Н. Самый новейший толковый словарь русского языка XXI века : ок. 1500 слов. М. : АСТ : Астрель, 2011. 413 с.

\section{REFERENCES}

Butseva T.N., Ridetskaya Yu.S., 2018. Neografiya i slovo goda [Neography and Word of the Year]. Russkiy yazyk $v$ shkole [Russian Language at School], no. 8, pp. 66-71.

Gak V.G., 1983. Novye slova i novye slovari [New Words and New Dictionaries]. Kotelova N.Z., ed. Novye slova i slovari novykh slov: sb. st. [New Words and Dictionaries of New Words. Collection of Articles]. Leningrad, Nauka Publ., pp. 15-29.

Gatsalova L.B., Parsieva L.K., 2015. Vozmozhnosti terminologicheskoy interpretatsii $\mathrm{i}$ leksikograficheskoye otrazheniye potentsialnykh slov [Possibilities of Terminological Interpretation and Lexicographic Reflection of Potential Words]. Vestnik Volgogradskogo gosudarstvennogo universiteta. Seriya 2. Yazykoznanie [Science Journal of Volgograd State University. Linguistics], no. 4 (28), pp. 138-143. DOI: http:// dx.doi.org/10.15688/jvolsu2.2015.4.17.

Dubichinskiy V.V., 2016. Osnovaniya neografii [The Grounds Are Not Clear]. Butseva T.N., ed. Neologiya $i$ neografiya: sovremennoe sostoyanie i perspektivy (k 50-letiyu nauchnogo napravleniya): sb. nauch. st. [Neology and Neography: Current State and Prospects (For the $50^{\text {th }}$ Anniversary of the Scientific Direction). Collection of Scientific Articles]. Saint Petersburg, Nestor-Istoriya Publ., pp. 41-47.

Dulichenko A.D., 1994. Russkiy yazyk kontsa XX stoletiya [Russian Language of the Late Twentieth Century]. Myunkhen, Sagner Publ. $347 \mathrm{p}$.

Katermina V.V., Solovyova N.S., 2019. Aksiologiya neologizma Brexit $\mathrm{v}$ angloyazychnom massmediynom diskurse [Axiology of 
Neologism Brexit in English Mass Media Discourse]. Aktualnye problemy filologii $i$ pedagogicheskoy lingvistiki [Current Issues in Philology and Pedagogical Linguistics], no. 3, pp. 103-111.

Kashtanova I.I., Biryukova O.A., Davydova E.A., 2018. Kontsept BREXIT $\mathrm{v}$ sovremennom angloyazychnom mediadiskurse [BREXIT Concept in the Modern English Media Discourse]. Filologicheskie nauki. Voprosy teorii i praktiki [Philology. Theory and Practice], no. 10, part 2, pp. 295-299.

Kotelova N.Z., 2015. Izbrannye raboty [Selected Works]. Saint Petersburg, Nestor-Istoriya Publ. $276 \mathrm{p}$.

Marinova E.V., 2011. Tak govorili v 90-e... Razmyshleniya nad stranitsami novogo slovarya [So They Said in the 90's... Reflections on the Pages of the New Dictionary]. Russkaya rech [Russian Speech], no. 5, pp. 118-125.

Mozyreva O.V., 2017. Breksit, Tinder i drugiye istochniki poyavleniya novykh slov [Brexit, Tinder and Other Sources of the Appearance of New Words]. Yazyk: kategorii, funktsii, rechevoye deystviye: materialy X yubileyn. Mezhdunar. nauch. konf. $k$ 75-letiyu Valeriya Stepanovicha Borisova [Language: Categories, Functions, Speech Action. Materials of the X Anniversary International Scientific Conference Dedicated to the $75^{\text {th }}$ Anniversary of Valery Stepanovich Borisov]. Moscow, Moskovskiy pedagogicheskiy gosudarstvennyy universitet, Gosudarstvennyy sotsialnogumanitarnyy universitet, pp. 117-120.

Butseva T.N., ed., 2016. Neologiya i neografiya: sovremennoye sostoyaniye $i$ perspektivy (k 50-letiyu nauchnogo napravleniya): $s b$. nauch. st. [Neology and Neography: Current State and Prospects (For the 50 $0^{\text {th }}$ Anniversary of the Scientific Direction). Collection of Scientific Articles]. Saint Petersburg, Nestor-Istoriya Publ. $236 \mathrm{p}$.

Kozlovskaya N.V., ed., 2020. Novye slova i slovari novykh slov. 2020: sb. nauch. st. [New Words and Dictionaries of New Words. Collection of Scientific Articles. 2020]. Saint Petersburg, ILI RAN. 220 p.

Ratsiburskaya L.V., ed., 2016. Novye tendentsii v russkom yazyke nachala XXI veka: kollektiv. monogr. [New Trends in the Russian Language of the Beginning of the $21^{\text {st }}$ Century. Collective Monograph]. Moscow, Flinta Publ., Nauka Publ. 304 p.

Popova M.A., 2008. Faktory i vektory protsessa neologizatsii sovremennogo russkogo yazyka [Factors and Vectors of the Neologization Process of the Modern Russian Language]. Izvestiya Volgogradskogo gosudarstvennogo pedagogicheskogo universiteta [Izvestia of the Volgograd State Pedagogical University], no. 2(26), pp. 72-75.

Shulezhkova S.G., 2019. Russkiye i bolgarskiye frazeologicheskiye neologizmy kak obyekt slovarnogo opisaniya [Russian and Bulgarian Phraseological Neologisms as Objects of Dictionary Description]. Nauchnyi dialog [Scientific Dialogue], no. 9, pp. 173-189. DOI: 10.24224/2227-1295-2019-9-173-189.

Shchetinina A.V., 2021. Vatnik, breksit i krymnash: k voprosu o leksikografirovanii novykh slov s semantikoy edineniya i vrazhdy [Lexicography of New Words with the Semantics of Unity and Enmity]. Nauchnyi dialog [Scientific Dialogue], no. 3,pp. 139-155. DOI: 10.24224/2227-1295-20213-139-155.

Nasseri M., 2016. Why was it "Brexit", not "Bristay"? A Note on the Psycholinguistic Effects of Message Exposure and Priming on Decision. URL: https://www.researchgate.net/publication/ 312191534_Why_was_it_Brexit_not_Bristay_ A_Note_on_the_Psycholinguistic_Effects_of Message_Exposure_and_Priming_on_ Decision_Making_Published_online_at_ httpwwwlalacademynetwhy-was-it-brexit-notbristay (accessed 20 March 2021).

\section{SOURCES AND DICTIONARIES}

Author's Archive.

Grigorenko O.V. Novye naimenovaniya lits $v$ sovremennom russkom yazyke: slov. materialy [New Names of Persons in the Modern Russian Language: Dictionary Materials]. Voronezh, Nauchnaya kniga Publ., 2009. 517 p.

Katlinskaya L.P. Tolkovyi slovar' novykh slov $i$ znacheniy russkogo yazyka: ok. 2000 slov [Russian Russian Russian Dictionary of New Words and Meanings. About 2000 Words]. Moscow, AST Publ., Astrel Publ., 2008. 380 p.

Krysin L.P. 1000 novykh inostrannykh slov: sprav. izd. [1000 New Foreign Words. Reference Edition]. Moscow, AST-PRESS KNIGA Publ., 2009. 320 p.

Natsionalnyi korpus russkogo iazyka [Russian National Corpus]. URL: www.ruscorpora.ru (accessed 2 February 2021).

Novikov V.I. Slovar' modnykh slov: yazykovaya kartina sovremennosti [Dictionary of Fashionable Words: The Linguistic Picture of Modernity]. Moscow, Slovari XXI veka Publ., $2018.351 \mathrm{p}$.

Novye slova i znacheniya. V 3 t. T. 3: slov.-sprav. po materialam pressy i lit. 90-kh godov XX veka. [New Words and Meanings. In 3 Vols. Vol. 3. 


\section{РАЗВИТИЕ И ФУНКЦИОНИРОВАНИЕ РУССКОГО ЯЗЫКА}

Dictionary-Reference Book on the Materials of the Press and Literature of the 90 s of the $20^{\text {th }}$ Century]. Saint Petersburg, Dmitry Bulanin Publ., 2014. 1360 p.

Okuntsova E.A. Noveyshiy slovar' inostrannykh slov: ok. 5000 slov i slovosochetaniy [The Newest Dictionary of Foreign Words. About 5000 Words and Phrases]. Moscow, Ayris-press Publ., 2009. $510 \mathrm{p}$.
Slovar' yazyka interneta.ru [Language Dictionary internet.ru]. Moscow, AST-PRESS KNIGAPubl., 2016. 288 p.

Shagalova E.N. Samyi noveyshiy tolkovyi slovar' russkogo yazyka XXI veka: ok. 1500 slov [The Newest Explanatory Dictionary of the Russian Language of the $21^{\text {st }}$ Century. About 1500 Words]. Moscow, AST Publ., Astrel Publ., 2011.413 p.

\section{Information About the Author}

Anna V. Shchetinina, Candidate of Sciences (Philology), Associate Professor, Department of Mass Communication Languages, Ural Federal University named after the First President of Russia B.N. Yeltsin, Mira St, 19, 620002 Yekaterinburg, Russia, anna-73.schetinina@yandex.ru, https://orcid.org/0000-0002-9085-8697

\section{Информация об авторе}

Анна Викторовна Щетинина, кандидат филологических наук, доцент кафедры языков массовых коммуникаций, Уральский федеральный университет им. первого Президента России Б.Н. Ельцина, ул. Мира, 19, 620002 г. Екатеринбург, Россия, anna-73.schetinina@yandex.ru, https://orcid.org/0000-0002-9085-8697 